Working Paper No. 612, 2004

Does Regulatory Harmonization Increase Bilateral Asset Holdings?

by Jonas Vlachos

IUI, The Research Institute of Industrial Economics

P.O. Box 5501

SE-114 85 Stockholm

Sweden 


\title{
Does Regulatory Harmonization Increase Bilateral Asset Holdings?^
}

\author{
First draft January 10, 2004 \\ This version, March 5, 2004
}

\author{
Jonas Vlachos
}

\begin{abstract}
By combining new data on bilateral asset holdings with data on securities regulation in an empirical gravity model, it is found that bilateral differences in securities regulation lead to decreased portfolio holdings. Hence, regulatory harmonization can foster financial integration. The results are especially strong for equity holdings. It is verified that the results do not just reflect general economic, institutional, and cultural differences. Additional analysis of causality shows the exogenous component of asset holdings to be associated with larger differences in securities regulation. This might suggest that regulatory differences are used to protect domestic capital markets from outside competition.
\end{abstract}

Keywords: Cross-border portfolio investments; Gravity model; Harmonization; Home bias; Integration; Securities regulation

JEL classification: F21; F36; G15; G18; K22

\footnotetext{
^I have benefited from comments by Mark Aguiar, Tore Ellingsen, Gita Gopinath, Alexander Mahler, Helena Svaleryd, Luigi Zingales and seminar participants at the University of Chicago. This paper was written the author was visiting the Graduate School of Business at the University of Chicago. Financial support from the Jan Hedelius and Tom Wallander Foundation is gratefully acknowledged. I am also grateful to Andrew Rose, Rafael La Porta, Florencio Lopez-de-Silanes, Andrei Shleifer and Robert Vishny for making their data publicly available in a user-friendly format.

- The Research Institute of Industrial Economics, P.O. Box 5501, SE-114 85 Stockholm, Sweden. Email: jonas.vlachos@iui.se. Phone:+46-8-6654537. Fax:+46-8-6654599.
} 


\section{Introduction}

This paper finds strong evidence that investors are more prone to hold portfolio assets in countries with similarly structured frameworks of securities regulation as their home country. The result implies that the harmonization of securities regulation can promote large increases in the integration of international capital markets. To any observer of the policy debate on the international aspects of securities regulation, this result is likely to seem obvious. For example, the conclusion reached in the European Commission's Financial Sector Action Plan (EU, 1999), and later the Lamfalussy Report (EU, 2001) was that the harmonization of regulatory standards is a definite pre-requisite for the creation of a truly integrated European capital market. In the global context, there are ongoing efforts to develop and coordinate regulatory frameworks through various standard-setting bodies and international financial institutions. ${ }^{1}$ However, that the harmonization of regulatory systems actually promotes financial integration is - to the best of my knowledge - an assertion made without backing of any systematic research prior to this study. ${ }^{2}$

To study the issue at hand, an empirical gravity model of bilateral portfolio holdings is estimated using data recently made available by the IMF. Indices of regulatory differences are constructed using data on securities regulation from La Porta et al. (2003) and on investor protection from La Porta et al. (1998). Rather than using the aggregate indices of regulatory quality derived by these authors, the sub-components of their indices are used to construct country-pair specific measures of regulatory differences. Home- and host-country fixed effects as well as standard controls for bilateral trade relations, including bilateral trade volumes and differences in the level of economic development, are introduced to rule out a spurious relationship. Although differences in both religious beliefs and general institutional quality appear to have strong negative impacts on bilateral asset holdings, it is verified that the results for regulatory differences remain robust even after taking these effects into

\footnotetext{
${ }^{1}$ Examples of standard setting bodies are the International Organization of Securities Commissions (IOSCO), the Basel Committee on Banking Supervision (BCBS), the International Accounting Standards Board (IASB), and the International Association of Insurance Supervisors (IAIS). Some of the main international financial institutions are the IMF, the World Bank and the OECD. Interaction between these also occurs. The IMF has for example, launched its Financial Sector Assessment Program that, among other things, documents compliance with the IOSCO standards. Jordan and Majnoni (2003) present a concise overview of the process of financial globalization and regulatory harmonization.

${ }^{2}$ This said, Buch (2003) finds that the adaptation of EU:s single market program and of the Basle capital accord has led to increased cross-border banking activity. Although this can be interpreted as being the result of the harmonization regulatory systems, the variables used by Buch do not directly measure regulatory differences between countries.
} 
account. Among the important further findings are the facts that the effect of regulatory differences is mainly at work among relatively rich countries, and that this effect is more pronounced for equity than for long-term debt holdings. As differences in the regulatory framework are derived using data mainly related to equity markets, this last finding offers further support for the conclusion of this paper.

Since it is plausible that the regulatory framework is harmonized between major investment partners, the direction of causality is a major issue. This problem is tackled using instrumental variables to investigate both how the exogenous component of regulatory differences affects bilateral asset holdings, and how the exogenous component of asset holdings affects regulatory differences. Surprisingly, instrumented asset holdings are found to be associated with larger regulatory differences. This offers support for the hypothesis that regulatory differences are sometimes used to protect domestic capital markets from outside competition (e.g. Rajan and Zingales, 2003).

Naturally, this is not the first study of the institutional determinants of international investments in a gravity setting. Improved data availability has resulted in a rapid increase in this literature. In a panel of countries, Portes and Rey (2003) find distance and other proxies of information costs to be good predictors of bilateral asset flows. These findings are confirmed by di Giovanni (2004) who estimates a gravity model for M\&A deals. He also finds that the level of financial development in the acquiring country is an important determinant of investments abroad. In a related study, Rossi and Volpin (2003) find that M\&A activity is higher in countries with better accounting standards and stronger shareholder protection. Consistent with di Giovanni, they also find that merger targets are usually located in countries with lower quality investor protection than that of the acquirers. Mody et al. (2003) estimate a somewhat different version of the gravity model and find host-country creditor rights to be positively related to the ratio between inward FDI and trade, but not to the ratio between portfolio inflows and trade. Wei (2000) estimates the impact of corruption on bilateral FDI flows and he finds that the negative impact of host-country corruption on inflows is even larger than the effect of host country taxation. Using a database on emerging market funds, Gelos and Wei (2002) find that mutual funds tend to hold less equity in countries with less transparent government and corporate disclosure. 
The present paper is also related to the large literature on the home bias of portfolio holdings. ${ }^{3}$ Recent contributions to this literature have stressed explanations based on informational rather than institutional factors. ${ }^{4}$ Since the results here suggest that regulatory differences can cause (or increase) informational costs, the possibility of separating these types of explanations may have been exaggerated.

Finally, the study is related to the literature on law and finance (starting with La Porta et al., 1998). Cross-country differences in securities regulation and investor protection appear to affect virtually all measurable aspects of domestic financing decisions. ${ }^{5}$ With the exception of the few studies mentioned above, the international dimension of these differences is, however, largely unexplored and this paper aims at filling this gap.

Regulatory harmonization and regulatory competition are also discussed in disciplines such as law, accounting, and political science. Although it is impossible to provide a comprehensive survey of this vast literature here, some of the main arguments will be presented in the next section.

\section{Motivation}

One of the basic motives for harmonizing securities regulation is to reduce the costs of investing in different markets. ${ }^{6}$ The lack of Europe-wide securities regulation is for example regularly blamed for hindering the integration of EU financial markets by raising the costs of cross-border financial intermediation (EU, 2001; Vives, 2001). The costs caused by regulatory heterogeneity involve the cost of learning about the regulatory system in various markets and the cost of obeying multiple regulations serving the same final objective. ${ }^{7}$ In the extreme, two regulatory systems can be mutually contradictory, thereby making compliance

\footnotetext{
${ }^{3}$ See Lewis (1999) for a survey.

${ }^{4}$ Coval and Moskowitz $(1999,2001)$ convincingly highlight the role of informational costs by first documenting a strong preference among investment managers for local assets even within the US, and then showing that fund managers earn abnormal returns on nearby investments.

${ }^{5}$ For evidence of the effect on domestic stock market development see La Porta et al. (1997, 2003); on the cost of capital, see Hali and Leuz (2003); on corporate earnings management, see Leuz et al. (2003); on the concentration of ownership and control, see La Porta et al. (1999). Note that this is just a partial list of the huge "law and finance" literature.

${ }^{6}$ Niemayer (2001) provides an analytical survey of the rationale behind securities regulation in general.

${ }^{7}$ Sykes (1999) provides an example: In order to ensure the solvency of banks, one country might impose capital adequacy regulation, while another country might directly regulate the riskiness of the banks' portfolios directly. Banks operating in both markets must incur the costs of complying with both regulations.
} 
with both logically impossible. Even in a situation where the domestic regulatory frameworks were completely harmonized, the international dimension might make the legal status of international securities contracts unclear, thereby increasing the costs of international investments. The differences in regulatory standards increase the costs of international investments even further. Given that harmonization reduces the cost of making cross-border investments, it would increase integration and competition in securities markets and hence ultimately increase the efficiency in global capital allocation.

These efficiency gains come at a cost, however. At least to some extent, regulatory differences reflect differences in tastes, values, needs and incomes across economies. Harmonization forcing authorities to deviate from the preferred regulatory framework can thus easily be welfare reducing. Another potential cost of harmonization is related to the dynamic aspects of regulatory development. Since it is difficult (or even impossible) to construct the perfect system of securities regulation from purely theoretical considerations, competition between regulatory systems can be crucial in learning about what works and what does not work in securities regulation. Harmonization runs the risk of limiting regulatory competition and hence, of lowering the long-term regulatory quality. Reforming already agreed upon international standards can also prove to be prohibitively cumbersome, thus increasing this risk even further. This said, the regulatory system is always susceptible to capture by interest groups aiming at using diverging regulatory standards in order to limit competition or in other ways serving narrow interests. Given the opacity of its regulatory framework, the financial sector might be especially vulnerable to such capture. ${ }^{8}$

Since the costs of reducing regulatory competition are extremely difficult to measure, a policy aimed at harmonizing regulations should be based on a clear understanding that it will achieve the benefits of increased market integration. This paper aims at increasing this understanding.

\section{Empirical method}

\footnotetext{
${ }^{8}$ A classic reference on the public-choice theory of regulation is Stigler (1971). Recently, Rajan and Zingales (2003) have found support for the idea that industry incumbents use financial regulation to protect domestic capital markets from outside competition. For a discussion of the difficult trade-offs connected to the harmonization of financial regulation, with a special emphasis on European company and takeover law, see Hertig and McCahery (2003).
} 
To asses the impact of differences in securities regulation on asset market integration, I use a gravity equation framework traditionally used to study international trade flows. The gravity equation links the logarithm of bilateral trade volumes to the joint exporter and importer GDP, as well as measures of distance between countries. ${ }^{9}$ Rather than using bilateral trade as the dependent variable, I use the logarithm of portfolio asset holdings in country $j$ by residents in country $i$. The set of explanatory variables is described below. The explanatory variable of main interest is an index of the differences in securities regulation between countries $i$ and $j$. Hence, the following baseline relationship is estimated using OLS:

$$
\begin{aligned}
\ln \left(1+\text { PORTINV }_{i j}\right)=\alpha_{1} \operatorname{SECREGDIFF}_{i j}+\alpha_{2} \ln \left(\text { DIST }_{i j}\right)+\alpha_{3} \ln \left(\text { GDPPCDIFF }_{i j}\right) \\
+\alpha_{4} \ln \left(\text { TRADE }_{i j}\right)+\alpha_{5} \text { COMLAN }_{i j}+\alpha_{6} \text { BORDER }_{i j}+\alpha_{7} \text { REGTRADE }_{\mathbf{i j}} \\
+\Sigma \alpha_{8, i} \mathrm{D}_{i}+\Sigma \alpha_{9, j} \mathrm{D}_{j}+\varepsilon_{i j} .
\end{aligned}
$$

PORTINV are portfolio asset holdings by country $i$ in country $j$, SECREGDIFF is the index of differences in securities regulation between $i$ and $j$, and DIST is the distance between the countries. GDPPCDIFF is the absolute value of differences in per capita GDP, meant to capture differences in general economic and institutional development. TRADE is the volume of bilateral trade which is highly correlated with portfolio investments and likely to be caused by similar underlying factors. COMLAN is a dummy for countries with a common language, BORDER is a dummy for countries sharing a land border, REGTRADE is a vector of dummies indicating that both countries are members of the EU, NAFTA, USIS (the US-Israel free trade agreement), ANZERTA, MERCOSUR, or ASEAN. $\mathrm{D}_{i}$ and $\mathrm{D}_{j}$ are sets of exporter and importer fixed effects, respectively, that capture all factors specific to the individual countries (among these the general quality of securities regulation). $\varepsilon$ is the error term. Since the standard errors are not independent across country-pairs, they are clustered at this level. Usually in a gravity setting, importer and exporter GDP and land area are controlled for. Here, the effect of these variables is captured by the fixed effects. In regressions without fixed effects, the log of the source and destination country GDP, GDP per capita, population size and land area are included as bilateral controls.

\footnotetext{
${ }^{9}$ For an up-to-date treatment of the theory and empirics on the gravity equation, see Feenstra (2004). Portes and Rey (2003) show that the gravity equation works well to explain bilateral asset flows. Rossi and Volpin (2003) and di Giovanni (2004) show similar results for bilateral M\&A deals, while Wei (2000) and Mody et al. (2003) successfully use this approach to explain bilateral FDI-flows.
} 
One important aspect of the empirical approach should be noted. The measure of regulatory differences takes on the same value for each country-pair. A symmetric effect for asset holdings by country A in country B and by country B in country A is therefore assumed. While this is indeed natural for a measure of regulatory differences, it is not natural for all types of variables. If, for example, country A had lower capital gains taxes than country B, this would simultaneously increase B's asset holdings in A and decrease A's holdings in B. The measure of tax differentials would naturally be positive when looking from A to B, and negative (and of the same size) in the opposite direction. This also implies that the variable would be orthogonal to regulatory differences. Hence, including variables of this type in the regressions would not affect the estimate of the impact of regulatory differences. Therefore, as long as the focus is on the impact of regulatory differences - and not on all possible determinants of bilateral asset holdings - only variables where the effect is expected to be symmetric for both source and destination countries must be included in the regressions.

Naturally, the direction of causality is a major concern in this type of a study. It is easy to imagine a situation where countries adjust their regulations in order to comply with the practices in their major investment partners. This behavior would then cause the point estimate on the index of regulatory differences to be downward biased (i.e. larger in absolute value). Another possibility is the reverse. As pointed out by Rajan and Zingales (2003), it is possible that countries use the regulation of financial markets as a protectionist tool to limit the competition from outsiders. If this were true, the point estimate on regulatory differences would be biased towards zero.

Measurement error is another problem that would cause a bias of the point estimates towards zero. Since any proxy for regulatory differences will be measured with error, this is a real concern. In order to deal with both this problem and the problem of reverse causality, instrumental variables will be extensively used in this study. ${ }^{10}$

\section{Data and measurement issues}

In this section, the data used are presented and discussed. Summary statistics of the variables are presented in Tables 1a (bilateral variables) and $1 \mathrm{~b}$ (country level variables).

\footnotetext{
${ }^{10}$ As long as the measurement errors of a variable and its instruments are uncorrelated, an IV procedure will solve the problem of the downward bias in the OLS-estimates (see e.g. Wooldridge, 2000).
} 


\subsection{Portfolio holdings}

Data on bilateral holdings of portfolio holdings are from the newly released Coordinated Portfolio Survey (CPIS) undertaken by the IMF. The purpose of this survey is to collect comprehensive data on the holdings of equity, and long- and short-term debt securities, broken down by the residence of the issuer for a wide range of countries. ${ }^{11}$ The data were collected in end-December 2001 and are valued at market prices.

The main variable of interest will be total portfolio holdings, the sum of the following subcomponents: Equity securities include all instruments and records acknowledging claims on the residual values of enterprises, after the claims of all creditors have been met. Shares, stocks, participations or similar documents (such as American Depository Receipts) usually denote ownership of equity. Long-term debt securities include instruments such as bonds, debentures, and notes that usually give the holder the unconditional right to a fixed cash flow or contractually determined variable money income and have an original term to maturity of more than one year. Short-term debt securities include treasury bills, commercial papers, and bankers' acceptances that usually give the holder the unconditional right to a stated fixed sum of money on a specified date. These instruments are usually traded on organized markets at a discount and have an original term to maturity of one year or less. Note that foreign direct investments are not included.

[Table 1a]

[Table 1b]

The residence of holders and issuers of securities is determined by their center of economic interest. For enterprises, banks, mutual funds and insurance companies, this is usually their legal domicile.

\subsection{Securities regulation}

\footnotetext{
${ }^{11}$ For a thorough presentation of the data and the methods used in collecting them, see IMF (2002). The data can be downloaded at http://www.imf.org/external/np/sta/pi/datarsl.htm.
} 
To construct proxies of the differences in securities regulation, this study draws heavily on the work on the legal framework regulating financial markets by La Porta et al. (e.g. 1998, 2003). These authors have greatly influenced the study of financial markets by both posing questions of how these markets are affected by different regulatory regimes, and making detailed indices of these regimes available to other researchers.

The most recent study by La Porta et al. (2003) presents an extensive examination of the securities laws in a wide selection of countries. The data underlying their paper are based on the answers to a questionnaire on the laws, statues and regulations on each country's major stock exchange as of December 2000, sent to attorneys in the sample of countries. In total, they report data on 21 sub-categories which are then classified between zero and one. Several indices regarding various aspects of securities regulations are constructed from these answers. The first of these is an index of the disclosure requirements of an issuer of new securities. The second indicates the "burden of proof" regarding questionable information in the prospectus for new securities issuance. These indices are then combined to a "private enforcement" index. Public enforcement securities regulation is taken into account by an index of the independence and effectiveness of the main supervisor of the securities markets, an index of the investigative powers of the main supervisor, an index of the non-criminal sanctions of securities laws violations, and an index of the criminal sanctions of securities violations. These indices are combined to form an index of "public enforcement".

Rather than focusing on the aggregate indices on regulatory quality presented in La Porta et al. (2003), however, I will use the sub-components of the different indices to create measures of the regulatory differences between each country-pair. In practice, this means that indices of the following type will be calculated (details on the exact construction of the indices are presented in the appendix):

Regulatory Difference $_{i j}=\Sigma\left|\mathrm{REG}_{t i}-\mathrm{REG}_{t j}\right|, t=1, \ldots, n$,

where $n$ is the number of sub-components of the original regulatory index, and $\mathrm{REG}_{t i}$ is the value of sub-component $t$ in country $i$. This way of measuring differences means that two countries can have regulatory frameworks of the same quality, while simultaneously displaying large differences in the regulatory structure. Since the underlying indices are additive, country-pairs where both trading partners have top (or bottom) quality of 
regulations, will also display zero differences in the structure of these. By necessity, the largest differences in regulatory structure will be between countries with high- and lowquality regulatory systems.

The most comprehensive index uses all 21 sub-categories reported by La Porta et al. and combines them into an index of total differences in securities regulation labelled SECREGDIFF. Table 2 shows the country-pairs with differences in SECREGDIFF in the lowest and highest percentiles and at the median. Just looking at the table suggests that differences in securities regulation reflect more than differences in general economic development. The largest difference can be found between the United States and Belgium, while one of the smallest differences is between the United States and the Philippines. Indeed, the correlation between SECREGDIFF and the absolute value of differences in per capita GDP is as low as 0.1 .

[Table 2]

In order to investigate the impact of differences in various aspects of securities regulation, I again follow La Porta et al. (2003) and construct an index of differences in disclosure rules (DISCLOSEDIFF) using six sub-categories, an index of differences in private enforcement (PRIVATEDIFF) using nine sub-categories, and an index of differences in public enforcement (PUBLICDIFF). All in all, the regulatory data overlap with the data on portfolio

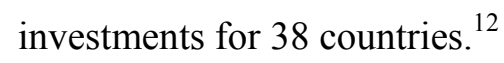

A caveat should be mentioned here. The original data are mainly focused on regulations regarding initial public offerings, rather than the general system of securities regulations. However, since these data are the most comprehensive data systematically documenting securities regulations for a large number of countries that I have found, it is highly likely that regulatory differences in this dimension will also be crude measures of the general differences in securities regulations.

\footnotetext{
12 The countries are Argentina, Australia, Austria, Belgium, Brazil, Canada, Chile, Colombia, Denmark, Egypt, Finland, France, Germany, Greece, Hong Kong, Indonesia, Ireland, Israel, Italy, Japan, South Korea, Malaysia, Netherlands, New Zealand, Norway, Philippines, Portugal, Singapore, South Africa, Spain, Sweden, Switzerland, Thailand, Turkey, United Kingdom. United States, Uruguay, Venezuela.
} 
Added to the above measures of regulatory differences, data from the highly influential "Law and Finance" paper by La Porta et al. (1998) on the protection of shareholders and creditors are used to construct three further indices of regulatory differences. The first of these uses all sub-indices to construct a "law-and-finance" difference index (LAWFINDIFF), the second uses differences in shareholder protection (SHAREPROTDIFF), and the third differences in creditor protection (CREDITORDIFF). These indices are constructed using the same methodology as above and will be used to check the robustness of the main results.

As instruments for differences in regulatory frameworks, I will follow much of the literature on finance and growth and use differences in legal origins from La Porta et al. (1998), and a dummy of shared colonial history from Rose (2002).

\subsection{Other bilateral variables}

Data on bilateral trade flows are from the year 1999 and are taken from Rose (2002). These data are originally from the IMF Direction of Trade Statistics. The value of bilateral trade is the average of exports and imports from $i$ to $j$ and from $j$ to $i$. Exports are FOB and imports are CIF. Since I am not interested in the coefficient of the trade variable per se, and trade flows are quite constant over time, the two-year discrepancy between the asset holding data and the trade data is of no major importance. Further, as opposed to the asset data, trade is a flow variable. Hence, it is not clear exactly which year should be used and empirically, the choice is of minor importance. ${ }^{13}$ From Rose (2002), I also get data on common language, common border, free trade agreements, and the distance between each country-pair. Data on religious beliefs are from Alesina et al. (2003), and data on cultural values are from Hofstede (2001).

\subsection{Country-specific data}

For some regressions, data for each individual country are needed. In addition to the variables mentioned above, I use an index of judicial efficiency from the International Country Risk Guide, an index of government effectiveness from Kaufman et al. (2003), the ratio of stock market trading to GDP from Beck et al. (2000), the ratio of small shareholders' stock market

\footnotetext{
${ }^{13}$ Using the average value of trade between 1997 and 1999 has a miniscule (third decimal) effect on the estimates of the various indices of regulatory differences.
} 
capitalization from La Porta et al. (2003), a dummy for membership in the EU (constructed by the author), and dummies for legal origins from La Porta et al. (1998). Data on land area, population, GDP and GDP per capita are from the World Bank World Development Indicators and relate to the year 2000.

\section{Results}

\subsection{Main results}

The main results are displayed in Table 3. The dependent variable is the logarithm of portfolio holdings in country $j$ by residents in country $i$. The first column shows the OLS-estimate of the dependent variable on the most comprehensive measure of differences in securities regulations, SECREGDIFF. The variable is highly statistically significant and negative, as expected. The coefficient of .05 implies that two countries moving their securities regulations one standard deviation "closer" to each other will experience a .13 log-point, or $\exp (.13)-1 \approx$ 14 percent, increase in their foreign ownership of portfolio assets.

As mentioned, the OLS-estimate is likely to be biased both because of reverse causality (that could yield both an upward and downward bias in the OLS-coefficients) and measurement error (that would cause a bias towards zero). In column two, two-stage-least-squares estimates are employed to remedy these problems. The instruments for differences in securities regulations are a dummy of differences in legal origin and a dummy of common colonial history. The F-statistics (38.5) of the instruments from the first-stage regression show to be very strong, and a Hansen test of over-identifying restrictions shows that they are valid to use as instruments (p-value 0.34$).{ }^{14}$ Now, the point estimate drops to -0.25 , implying an increase in asset holdings from a one standard deviation decrease in differences in securities regulations by 88 percent! While this effect is very large (almost implausibly large), it should be kept in mind that the indicator of differences in securities regulation is very crude. The result is therefore not to be viewed as a precise estimate of the impact of regulatory differences. Rather, it is indicative of the importance of these differences.

\footnotetext{
${ }^{14}$ It is possible to argue that that the dummy for shared colonial history should be included as a RHS-variable in its own right. When this is done, and legal origin is used as the only instrument, the colonial dummy is not statistically significant ( $\mathrm{p}$-value .4). The standard error on SECREGDIFF is somewhat increased but the point estimate is stable and still statistically significant (p-value .03). This, together with the OID-tests, suggests that colonial history is a valid instrument for regulatory differences.
} 
Since the purpose of this study is mainly to unravel the causal effect of differences in securities regulation on asset holdings, I postpone the problem of disentangling whether the difference in point estimates between the OLS and 2SLS estimates is due to measurement error or negative reverse causality to Section 5.7. ${ }^{15}$

The empirical specification does a very good job in explaining bilateral portfolio holdings. The R-squared is around .86 and most of the explanatory variables have the expected signs. Countries remote from each other, both geographically and economically, have smaller asset holdings. Bilateral trade volumes are strongly positively related to portfolio trade. Countries sharing a common language invest more in each other's markets, as do, in general, countries belonging to the same free-trade areas. There are two oddities, however. First of all, the common land border dummy has a negative sign, as does the dummy for NAFTAmembership. Regarding the border dummy, this seems to be due to the inclusion of both bilateral trade and distance in the regressions. Dropping these two variables from the regression makes the border-variable take on a positive sign. The NAFTA-dummy remains negative, though, and there seems to be no other explanation than that the NAFTA-members invest less in each other than expected, given their other characteristics.

[Table 3]

In columns three to eight, the results are presented using the various sub-indices of differences in securities regulations described above. The first of these is based on the differences in disclosure regulations, the second on differences in private enforcement of securities regulation, and the third on differences in public enforcement of securities regulation. All of these are highly statistically significant and carry the expected negative sign. Considering the OLS-estimates, the implied size of the effect of harmonized securities regulations is relatively constant across these specifications. The 2SLS-estimates are more volatile and even larger than the estimate using the aggregate difference index.

\subsection{Another look at the size of the effects}

\footnotetext{
${ }^{15}$ As mentioned before, the possibility of a negative causal effect for protectionist reasons has been discussed by Rajan and Zingales (2003).
} 
The results in the previous section imply that policy makers in a country can choose to increase the asset holdings of foreigners from a certain country by harmonizing the structure of securities regulations with this country. In practice, this is difficult to accomplish without improving or worsening the overall quality of the regulatory framework. In order to investigate how the quality and structure of securities regulation are related, I now include the country-specific indices of regulatory quality in the regressions. To achieve this, the countryfixed effects must be dropped from the specifications and a set of control variables for both the source and destination countries be added. ${ }^{16}$ It should be noted that I do not use exactly the same scaling of the regulatory indices as La Porta et al. (2003). To make their scale comparable to the indices of regulatory differences, I just add the different sub-components of the respective index. Using the original indices yields virtually identical results. Because of the problems related to the OLS-estimates, I only run these regressions using 2SLS and add dummies of legal origins for both source and destination to the set of instruments. To facilitate comparisons of the effects, I also run all regressions using a log-log specification where the regulatory indices are converted by taking the logarithm of (one plus) the original indices. These results are presented in Panel B of Table 4.

\section{[Table 4]}

Although the indices of regulatory quality in both the source and destination country are positive, only the destination country's regulatory quality is robustly significant. The interpretation of this result is that the improvement of domestic securities regulation will attract more foreign portfolio investments. ${ }^{17}$ The size of the coefficient on SECREG suggests that an increase in this index by one standard deviation (3.77 points) will increase foreign portfolio holdings by about 40 percent. Such a change would, on the other hand, also lead to a change in the difference index, SECREGDIFF. The total effect on foreign asset holdings thus depends on how SECREGDIFF is affected on average. A country that simultaneously moves its securities regulations by 3.77 points towards all other countries' regulatory framework would experience another 150 percent increase in foreign asset holdings. It is, however,

\footnotetext{
${ }^{16}$ Given that the fixed effects capture all country-specific factors, there is virtually no end to the variables that could potentially be added to the regressions. For both the source and destination country, I add the log of per capita GDP, external market capitalization, an index of judicial efficiency, an index of government effectiveness, the value traded in the stock market to GDP ratio, a dummy variable for EU membership, and the log of population size. In addition, the log of the product of source and destination country land area and GDP are included. I chose this set of controls since it brings the estimates close to those using fixed effects.

${ }^{17}$ This is consistent with the findings in Alfaro et al. (2003). They document that broad measures of institutional quality are strongly positively related to capital inflows.
} 
possible to construct a scenario where the improvement of domestic regulation actually makes foreign investors more reluctant to hold securities in a certain country. Panel B of the table carries the same message, although its coefficients can be read as elasticities. A one percent increase in SECREGDIFF reduces the foreign asset holdings by almost two percent, while a one-percent increase in SECREG increases foreign asset holdings by about one percent. The pattern that a one-percent change in the difference-index yields about twice as large an effect as a one-percent change in the original index holds for all four indices of securities regulation.

Given that the objective of policy makers is to increase global asset market integration, the relative size of these effects is a strong call for internationally coordinated policy making even if this contributes to reducing regulatory standards in some countries. Naturally, policy coordination is better at a higher level than at a lower level of quality, but if a trade-off is necessary, coordination might be preferred. Although these results are quite straightforward, it should be clear that this study has nothing to say concerning the long-term, potentially detrimental, learning effects of reducing the number of ways in which securities markets are regulated.

\subsection{Rich and poor countries}

It is plausible that differences in securities regulation have different impacts at different levels of economic development. In this section, the sample of countries is split in several ways according to the median value of per capita GDP in order to address this issue. In column (1) of Table 5, only countries with above the median per capital GDP are included, and in column (2), only countries below. While the original results hold for the sample of relatively rich countries, there is no indication that differences in securities regulation affect asset holdings among poor countries. In other words, it could be the case that the importance of regulatory differences only begins to matter after some fundamental level of economic and regulatory development has been reached.

[Table 5]

In column (3), all source countries are included, but only the destination countries with a relatively high per capital GDP. Once more, the original results hold. In column (4), all source countries are once again included, but only low income destinations. The point estimate on 
SECREGDIFF is again similar to the original ones, but it is now only statistically significant at the 10-percent level. In column (5), all destination countries are included, but only highincome source countries. The point estimate is smaller, but still significant, both in the economic and statistical sense. Column (6) includes all destinations, but only low income source countries. The effect is now marginally statistically significant, but the point estimate is about the same as the original one. Taken together, these results indicate that while investors from both rich and poor countries are influenced by the differences in securities regulation, rich-country investors seem to be more sensitive in this dimension.

\subsection{The difference between equity and long-term debt holdings}

So far, the total level of bilateral securities assets has been used as the dependent variable. It is, however, possible that the differences in securities regulations have different effects on various types of asset holdings. Indeed, since the regulatory indices are mainly based on rules governing the issuance of new shares, they would be expected to have a stronger impact on equity than on debt holdings (especially since debt holdings include government bonds). For this reason, Table 6 presents the results from regressing equity holdings and long-term debt holdings by country $i$ in country $j$, respectively, on the four different indices of differences in securities regulation.

[Table 6]

Although all coefficients on the indices of regulatory difference are consistently negative, it is obvious from Table 6 that the impact of regulatory differences is greater on bilateral equity holdings than on long-term debt holdings, just as expected. This is highly indicative of the indices capturing the regulatory effects they are meant to, rather than the effect of some omitted relationships between country-pairs. In fact, Table 6 provides further evidence for this view. The tests for over-identifying restrictions show that while differences in legal origin and colonial history (the instruments) are not correlated with the error terms in the equity regressions, they are so in the debt regressions. This suggests that debt issues (which include

government debt), to a significant extent are placed in countries with which the issuing country has a shared history. On the other hand, no such independent effect of shared history can be found for equity holdings. 
The next section presents some further evidence of the view that differences in the regulation of debt markets and equity markets have asymmetric effects on bilateral debt and equity holdings.

\subsection{Differences in investor protection}

As mentioned in Section 4, we should keep in mind that the indices of differences in securities regulation are based on data focusing on the regulation of initial public offerings, rather than securities regulation in general. To partly remedy this problem and to verify the robustness of the results, three difference indices based on the data on shareholder and creditor protection from the "Law and Finance" paper by La Porta et al. (1998) are used. The most comprehensive index LAWFINDIFF, is based on all sub-components in the original data. SHAREPROTDIFF is based on the differences in shareholder protection, and CREDITORDIFF is based on the differences in creditor protection. Table 7 presents the results from regressing total bilateral asset holdings, equity holdings, and long-term debt holdings, respectively, on each of these indices.

\section{[Table 7]}

The first three columns show that the most comprehensive index of differences in investor protection has a similar effect on bilateral asset holdings as differences in securities regulation (column 1). The main difference is that the effect is almost symmetric for equity holdings (column 2) and long-term debt holdings (column 3).

Differences in the protection of shareholders also have a strong impact on bilateral asset holdings (column 4), but the effect of this variable is, not surprisingly, stronger for equity holdings (column 5) than for long-term debt (column 6). The effect of differences in creditor protection is less statistically significant, but the point estimates are consistently negative. Although the difference is not large, there is some indication that differences in creditor protection are of greater importance for debt than for equity holdings.

The results in Table 7 seem to suggest that differences in the regulation of equity markets limit bilateral equity holdings, while differences in the regulation of debt markets limit 
bilateral debt holdings. Although this is undoubtedly both intuitive and appealing, the crudeness of the data renders the evidence on these issues mainly indicative.

\subsection{Further robustness}

In this section, a further set of robustness tests are performed. Although the main results are stable to the tests, it is found that differences in general institutional quality and in religious beliefs have negative impacts on bilateral asset holdings.

[Table 8]

\subsubsection{Excluding the hubs of international finance and trade}

First of all, the United States and the United Kingdom are very much the hubs around which the international financial system revolves. For this reason, it is possible that observations including these countries have a disproportionate effect on the results. In column 1 of Table 8 , I therefore run the baseline specification excluding the US and the UK. As can be seen, the results are basically unaffected by this exclusion. I then exclude Singapore and Hong Kong (column 2) since these economies are exceptionally open to international trade and finance. Once again, the results do not change substantially.

\subsubsection{Differences in institutional quality}

Another possibility is that the indices of regulatory differences pick up effects from differences in general institutional quality, rather than from the regulatory structure per se. I therefore calculate the (absolute) difference in each of some commonly used indicators of institutional quality for each country-pair. The indicators are the Rule of Law Index from International Country Risk Guide (ICRG) and the index of Government Effectiveness from Kaufmann et al (2003). As can be seen in columns (3) and (4) of Table 8, the basic results do not change substantially because of these inclusions. This is a strong indication that the index of differences in securities regulation does not just serve as a proxy for general institutional 
quality differences. ${ }^{18}$ Even though not the focus of the present paper, it is nevertheless interesting to note that differences in rule of law take on negative and statistically significant values (as do differences in corruption and the risk of expropriation). This suggests that investors prefer to invest in countries with similar levels of institutional quality as their home country.

\subsubsection{Differences in culture}

Next, the possibility that the differences in regulation mainly proxy for cultural differences is controlled for. This is first done by constructing an index of differences in religious beliefs between country-pairs. Looking at differences in religion is attractive, since the definitions of religious groupings are relatively constant across countries. The index is derived by summing over the squared differences in the share of the population belonging to a certain religious group. Algebraically,

Religious Difference $_{i j}=\sum\left(\text { Share }_{r i}-\text { Share }_{r j}\right)^{2}, r=1, \ldots m$,

where $m$ is the number of religious groups and Share ${ }_{r i}$ the share of the population in country $i$ belonging to religion $r .^{19}$ This index is increasing in the differences in beliefs between countries. The underlying data for religious beliefs are taken from Alesina et al. (2003). The results from including this variable are shown in column (5) of Table 8. The point estimate is negative (as expected) and highly statistically significant. The point estimate of SECREGDIFF is somewhat reduced, but it remains highly significant, both in the economic and statistical sense. Once again, an interesting secondary result is discovered, but I leave it to future research to further investigate the link between religious differences and international investments.

A second measure of cultural differences is calculated using the work of the cultural anthropologist Hofstede (2001). He used personnel data on IBM employees around the world to classify national cultures along four dimensions: power distance (the acceptance of an

\footnotetext{
${ }^{18}$ I have also used the Corruption Perception Index from Transparency International, and the Risk of Expropriation Index from ICRG with very similar results. Entering all four institutional indicators simultaneously does not change the results. These results are available upon request.

${ }^{19}$ The following religious groupings are used: Buddhist, Catholic Christian, Hindu, Jewish, Muslim, Non religious, Other Christians, Orthodox Christian, Protestant Christian, Shinto. Muslims are not divided into Shiites and Sunnis since there is not a significant share of Shiites in this sample of countries.
} 
unequal distribution power in an organization), the degree of individualism, uncertainty avoidance (related to risk aversion), and masculinity (related to gender inequality). ${ }^{20}$ Each of these dimensions was assigned a score between 0-100 for each country. An index is then constructed by summing the absolute value of differences between country pairs for each of the cultural dimensions. Algebraically,

Cultural Difference $_{i j}=\sum \mid$ Culture Dimension $_{c i}-$ Culture Dimension $_{c j} \mid, c=1,2,3,4$,

where Culture Dimension $c i$ is the value of dimension $c$ in country $i$. In column (6) of Table 8, it can be seen that this variable takes on a negative coefficient but the statistical significance is just below the conventional levels. The results for the index on differences in securities regulation are once again unaffected.

Finally, in column (7), all four new variables (differences in rule of law, government effectiveness, religious beliefs, and cultural values) are included. The basic results also hold up for this exercise.

\subsection{The direction of causality revisited}

As mentioned in Sections 3 and 5.1, the increase in coefficient size when running 2SLS regressions rather than OLS regressions can be explained in two different ways. First, the 2SLS estimator could be solving a measurement error problem in the explanatory variable that causes the OLS estimates to be biased towards zero. Second, the reverse causality could actually be negative, thereby implying that countries attempt to differentiate their regulatory systems from their main trading partners. In this section, I will present some crude attempts at discriminating between these hypotheses, and find support for the latter. This offers support for the Rajan and Zingales (2003) hypothesis that the regulation of financial markets is sometimes used to protect domestic capital markets from outside competition.

To investigate the sign of the reverse causality, I first let bilateral portfolio holdings and differences in securities regulation switch places in the regression, thereby letting differences in securities regulation be explained by portfolio holdings rather than the other way around. In

\footnotetext{
${ }^{20}$ It is impossible to here give full credit to the strengths and weaknesses of Hofstede's approach. The interested reader should start by consulting Hofstede (2001) and the references therein.
} 
addition, the following explanatory variables are included: differences in legal origin and common colonial past (the instruments from the previous 2SLS regressions), the common border dummy, geographic distance, the common language dummy, differences in per capita GDP, the value of bilateral trade, dummies for various regional trading arrangements, and importer and exporter fixed effects.

[Table 9]

The OLS estimates from this regression are presented in column 1 of Table 9. Naturally, the partial correlation between differences in securities regulation and bilateral asset holdings is negative. Differences in legal origin are associated with larger differences in the regulatory framework, and common colonial past with smaller differences (which of course is why these variables work as instruments), a larger geographical distance is associated with larger regulatory differences, while sharing a common border dummy seems to increase these differences. The common language dummy is associated with smaller differences, while differences in per capita GDP are not statistically significant. Trade volumes are negatively related to regulatory differences, but only with marginal statistical significance. The free-trade area dummies take on both negative and positive signs.

While these results are all interesting, the causal effect remains to be established. For this purpose, I instrument bilateral asset holdings with the product of (the log of) population size, the product of (the log of) GDP, and the absolute value of differences in the rule of law index. ${ }^{21}$ Population size and GDP are likely to be positively related to the level of bilateral asset holdings, but there is no reason to expect them to have an effect on differences in the regulatory framework. ${ }^{22}$ Using the difference in the rule of law index as an instrument is more questionable, but we know from Table 8 that this variable is an important determinant of bilateral asset holdings. At the same time, it is basically uncorrelated with differences in securities regulation. ${ }^{23}$ Hence, the instrumented coefficient on bilateral asset holdings tells us how the exogenous component of asset holdings is associated with the regulatory framework.

\footnotetext{
${ }^{21}$ This is equivalent to estimating the second equation of a system using a three-stage least squares procedure, while forcing the covariance matrix of equation disturbances to be diagonal. One equation in the system is the 2SLS estimation with $\ln (1+$ PORTINV) as the dependent variable, and the other is the 2SLS estimation with SECREGDIFF as the dependent variable. Performing a full 3SLS, also using the parameter variance between the equations has no important effect on the results (the standard errors become marginally smaller).

${ }_{22}$ Including these two variables in the baseline regressions does not affect the results to any significant degree.

${ }^{23}$ The correlation coefficient is -0.03 and is not statistically significant.
} 
Column 2 of Table 9 shows this effect to be positive and statistically significant at the fivepercent level. The F-test (test statistics 9.78) indicates that the instruments have reasonable explanatory power and the test of over-identifying restrictions tells us that the instruments are valid (p-value 0.31).

This is a strong indication that while there is indeed an endogeneity problem in the OLS regression of bilateral asset holdings on differences in securities regulation, this endogeneity problem causes an upward (towards zero) bias in the OLS estimates. A less statistical interpretation is that regulatory authorities are inclined to construct regulatory frameworks differing from those of the main asset trading partners.

\section{Conclusion}

Data on securities regulation and investor protection presented in La Porta et al. (1998, 2003) are used in a novel way to calculate indices of bilateral differences in regulatory policies. Combining these indices with data on bilateral asset holdings, it is found that the harmonization of securities regulation can potentially have very large effects on the integration of securities markets. It is verified that these effects do not only reflect general differences in economic development, institutional quality, and cultural values. This said, both differences in institutional quality and religious beliefs tend to decrease bilateral asset holdings. When investigating causality, it is found that the exogenous component of bilateral asset holdings appears to be associated with larger differences in securities regulation. This offers support for the idea presented by Rajan and Zingales (2003) that financial regulation can be used to protect domestic capital markets from outside competition.

This is by no means the final word on the consequences (and causes) of harmonized securities regulation. First of all, there are several ways of measuring capital market integration, and using other measures than aggregate asset holdings can yield further insights into the mechanisms at work. Second, due to the crudeness of the regulatory data, the present paper must take the view that all regulatory differences are equal. This is most likely not true, so another priority for future research is constructing more detailed measures on various aspects of regulatory differences. Further, the ideal data for investigating these questions would also include the time dimension. Time-varying measures of bilateral asset holdings (or flows) and regulatory changes could then be used to better establish the size of the causal effect than 
what is possible using the present instrumental variables approach. Another interesting area of research would be to focus on a single industry, like the banking sector. This way, the task of constructing more detailed, and possibly time-varying, measures of regulatory differences could prove less daunting.

It should be clear that a number of important issues are not being addressed here. It could for example, be the case that regulatory harmonization has positive - or negative - effects on domestic financial development. ${ }^{24}$ More generally, this study teaches us little about the longterm effects of harmonization. To some extent, the existence of different regulatory systems provides lessons regarding the effectiveness of various regulatory tools. Hence, long-term regulatory development can be impeded if harmonization is taken too far. ${ }^{25}$ This study is also silent on what the optimal level of harmonization is, what regulatory powers should be left for national authorities, what should be in the hands of supra-national authorities, should harmonization be created by minimum or maximum standards, and so on.

A further investigation of the results for institutional and religious differences is also warranted. The results here indicate that differences along both these dimensions influence the choice of country in which to invest. Although these results appear very strong, it remains to be seen how they stand up to closer scrutiny.

Although the findings in this paper are important in their own right, it could be that the main contribution is methodological. By exploiting the growing number of datasets on various aspects of bilateral linkages, there is ample scope for studying the interactions between institutions and markets in ways not possible using standard cross-country data. The method displays some similarities to that used by Fisman and Love (2004). They study how differences in economic and financial development affect the correlation of industry growth rates between countries. The fact that their line of inquiry is very different from the one here should only highlight the potential of the approach.

\footnotetext{
${ }^{24}$ It is, for example, possible that the optimal regulatory framework in an economy with dispersed stock ownership (like the US) is different than in an economy with concentrated ownership (like most of Europe). For a discussion of the different possible impacts the same takeover legislation can have in heterogeneous economies, see Berglöf and Burkhart (2003).

${ }^{25}$ The new Germany bankruptcy law provides an illustrative example. It was recently updated and it now provides the option of Chapter 11-type restructuring. Had the US experience with Chapter 11 not existed because of harmonization, it is not certain that the German authorities would have come up with this idea.
} 


\section{References}

Alesina, Alberto, Arnaud Devleeschauwer, William Easterly, Sergio Kurlat, Romain Wacziarg (2003) "Fractionalization”, Journal of Economic Growth 8:2, 155-194.

Alfaro, Laura, Sebnem Kalemli-Ozcan, Vadym Volosovych (2003) "Why doesn't Capital Flow from Rich to Poor Countries? An Empirical Investigation", mimeo University of Houston.

Beck, Thorsten, Ross Levine, Norman Loayza (2000) "Financial Intermediation and Growth: Causality and Causes", Journal of Monetary Economics 46, 31-77.

Berglöf, Erik and Mike Burkart (2003) "European Takeover Regulation", Economic Policy 36, 171-208.

Buch, Claudia M. (2003) "Information or Regulation: What Drives the International Activities of Commercial Banks?”, Journal of Money, Credit and Banking 35:6, 851-870.

Coval, Joshua D. and Tobias J. Moskowitz (1999) "Home Bias at Home: Local Preference in Domestic Portfolios", Journal of Finance 54:6, 2045-2073.

Coval, Joshua D. and Tobias J. Moskowitz (2001) "The Geography of Investments: Informed Trading and Asset Prices", Journal of Political Economy 109:4, 811-841.

di Giovanni, Julian (2004) "What Drives Capital Flows? The Determinants of Cross-Border M\&A Deals", forthcoming Journal of International Economics.

EU (1999) "Financial Services. Implementing the Framework for Financial Markets: Action Plan". Available at: http://europa.eu.int/comm/internal_market/en/finances/general/actionen.pdf.

EU (2001) "Final Report of The Committee of Wise Men on the Regulation of European Securities Markets“. Available at:

http://europa.eu.int/comm/internal_market/en/finances/general/lamfalussyen.pdf.

Feenstra, Robert C. (2004) Advanced International Trade: Theory and Evidence, Princeton University Press: Princeton N.J.

Fisman, Raymond and Inessa Love (2004) "Financial Development and Intersectoral Allocation: A New Apporach", forthcoming Journal of Finance.

Gelos, R. Gaston and Shang-Jin Wei (2002) "Transparency and International Investor Behavior", IMF Working Paper 02/174.

Hail, Luzi and Christian Leuz (2003) "International Differences in the Cost of Capital: Do Legal Institutions and Securities Regulation Matter?”, ECGI Working Paper 15/2003.

Hertig, Gerard and Joseph A. McCahery (2003) "Company and Takeover Law Reforms in Europe: Misguided Harmonization Efforts of Regulatory Competition?”, ECGI Working Paper 12/2003. 
Hofstede, Geert H. (2001) Culture's Consequences: Comparing Values, Behaviors, Institutions, and Organizations across Cultures, Sage Publications: Thousand Oaks, CA.

IMF (2002) "Coordinated Portfolio Investment Survey Guide, $2^{\text {nd }}$ Edition", The IMF Publication Services: Washington DC. Available at:

http://www.imf.org/external/pubs/ft/cpis/2002/pdf/cpis_index.pdf.

Jordan, Cally and Giovanni Majnoni (2003) "Financial Regulatory Harmonization and the Globalization of Finance" in James A. Hansson, Patrick Honohan, Giovanni Majnoni (eds.) Globalization and National Financial Systems, World Bank: Washington D.C.

Kaufman, Daniel, Aart Kraay, Massimo Mastruzzi (2003) "Governance Matters III: Governance Indicators for 1996-2002”, World Bank. Data available at:

http://www.worldbank.org/wbi/governance/govdata2002.

La Porta, Rafael, Florencio Lopez-de-Silanes, Andrei Shleifer, Robert W. Vishny (1997) "Legal Determinants of External Finance", Journal of Finance 52:3, 1131-1170.

La Porta, Rafael, Florencio Lopez-de-Silanes, Andrei Shleifer, Robert W. Vishny (1998) "Law and Finance", Journal of Political Economy 106(6), 1113-1155.

La Porta, Rafael, Florencio Lopez-de-Silanes, Andrei Shleifer (1999) "Corporate Ownership Around the World", Journal of Finance 54, 471-517.

La Porta, Rafael, Florencio Lopez-de-Silanes, Andrei Shleifer (2003) "What Works in Securities Laws?", mimeo Harvard University.

Leuz, Christian, Dhananjay Nanda, Peter D. Wysocki (2003) "Earnings Management and Investor Protection: An International Comparison", Journal of Financial Economics 69, 505527.

Lewis, Karen (1999) "Trying to Explain Home Bias in Equities and Consumption”, Journal of Economic Literature 37:2, 571-608.

Mody, Ashoka, Assaf Razin and Efraim Sadka (2003) "The Role of Information in Driving FDI flows: Host Country Transparency and Source Country Specialization", NBER Working Paper 9662.

Niemayer, Jonas (2003) "An Economic Analysis of Securities Market Regulation and Supervision: Where to Go after the Lamfalussy Report?”, SSE/EFI Working Paper \#482.

Portes, Richard and Hélèn Rey (2003) "The Determinants of Cross-Border Capital Flows", Working Paper Princeton University.

Rajan, Raghuram and Luigi Zingales (2003) "The Great Reversals: The Politics of Financial Development in the Twentieth Century", Journal of Financial Economics 69(1), 5-50.

Rose, Andrew K. (2002) "Do We Really Know that the WTO Increases Trade?", NBER WP \#9273. 
Rossi, Stefano and Paolo Volpin (2003) "Cross-Country Determinants of Mergers and Acquisitions”, ECGI Working Paper 25/2003 forthcoming Journal of Financial Economics.

Stigler, George (1971) “The Theory of Economic Regulation”, Bell Journal of Economics 2:1, $3-21$.

Sykes, Alan O. (1999) "The (Limited) Role of Regulatory Harmonization in International Goods and Service Markets”, Journal of International Economic Law 2:1, 49-70.

Vives, Xavier (2001) "Restructuring Financial Regulation in the European Monetary Union", Journal of Financial Services Research 19:1, 57-82.

Wei, Shang-Jin (2000) "How Taxing is Corruption on International Investors?", Review of Economics and Statistics 82:1, 1-11.

Wooldridge, Jeffrey M. (2000) Introductory Econometrics: A Modern Approach, SouthWestern: New York. 


\section{Appendix. Constructing indices of regulatory differences}

For each country-pair $i j$, a set of indices of regulatory differences is constructed using the following methodology: Regulatory difference $e_{i j}=\Sigma\left|\mathrm{REG}_{t, i}-\mathrm{REG}_{t, j}\right|, t=1, \ldots, n$, where $t$ is the individual sub-index presented below.

Table A1. Sub-indices from "What works in Securities Laws?", La Porta et al. (2003).

$\begin{array}{ll}\text { Sub-index } & \text { Description } \\ \text { Prospectus } & \begin{array}{l}\text { Equals one if the law prohibits selling securities that are going to be listed on the largest stock } \\ \text { exchange of the country without delivering a prospectus to potential investors; equals zero otherwise. }\end{array}\end{array}$

Sharehol An index of disclosure requirements regarding the Issuer's equity ownership structure. Equals one if the law or the listing rules require disclosing the name and ownership stake of each shareholder who, directly or indirectly, controls ten percent or more of the Issuer's voting securities; equals one-half if reporting requirements for the' Issuer's $10 \%$ shareholders do not include indirect ownership or if only their aggregate ownership needs to be disclosed; equals zero when the law does not require disclosing the name and ownership stake of the Issuer's $10 \%$ shareholders. No distinction is drawn between large-shareholder reporting requirements imposed on firms and those imposed on large shareholders themselves.

Compensa An index of prospectus disclosure requirements regarding the compensation of directors and key officers. Equals one if the law or the listing rules require that the compensation of each director and key officer be reported in the prospectus of a newly-listed firm; equals one-half if only the aggregate compensation of directors and key officers must be reported in the prospectus of a newly-listed firm; equals zero when there is no requirement to disclose the compensation of directors and key officers in the prospectus for a newly-listed firm.

Insideow An index of prospectus disclosure requirements regarding the equity ownership of the Issuer's shares by its directors and key officers. Equals one if the law or the listing rules require that the ownership of the Issuer's shares by each of its director and key officers be disclosed in the prospectus; equals onehalf if only the aggregate number of the Issuer's shares owned by its directors and key officers must be disclosed in the prospectus; equals zero when the ownership of Issuer's shares by its directors and key officers need not be disclosed in the prospectus.

Contract An index of prospectus disclosure requirements regarding the Issuer's contracts outside the ordinary course of business. Equals one if the law or the listing rules require that the terms of material contracts made by the Issuer outside the ordinary course of its business be disclosed in the prospectus; equals one-half if the terms of only some material contracts made outside the ordinary course of business must be disclosed; equals zero otherwise.

Transact An index of the prospectus disclosure requirements regarding transaction between the Issuer and its directors, officers, and/or large shareholders (i.e., "related parties"). Equals one if the law or the listing rules require that all transactions in which related parties have, or will have, an interest be disclosed in the prospectus; equals one-half if only some transactions between the Issuer and related parties must be disclosed in the prospectus; equals zero if transactions between the Issuer and related parties need not be disclosed in the prospectus.

Bdn dire Index of the procedural difficulty in recovering losses from the Issuer's directors in a civil liability case for losses due to misleading statements in the prospectus. Equals one when investors are only required to prove that the prospectus contains a misleading statement. Equals two-thirds when investors must also prove that they relied on the prospectus and/or that their loss was caused by the misleading statement. Equals one-third when investors prove that the director acted with negligence and that they either relied on the prospectus or that their loss was caused by the misleading statement or both. Equals zero if restitution from directors is unavailable or the liability standard is intent or gross negligence.

Bdn dist Index of the procedural difficulty in recovering losses from the Distributor in a civil liability case for losses due to misleading statements in the prospectus. Equals one when investors are only required to prove that the prospectus contains a misleading statement. Equals two-thirds when investors must also prove that they relied on the prospectus and/or that their loss was caused by the misleading statement. Equals one-third when investors prove that the Distributor acted with negligence and that they either relied on the prospectus or that their loss was caused by the misleading statement or both. Equals zero if restitution from the Distributor is unavailable or the liability standard is intent or gross negligence.

Bdn acco Index of the procedural difficulty in recovering losses from the Accountant in a civil liability case for losses due to misleading statements in the audited financial information accompanying the prospectus. Equals one when investors are only required to prove that the audited financial information accompanying the prospectus contains a misleading statement. Equals two-thirds when investors must also prove that they relied on the prospectus and/or that their loss was caused by the misleading accounting information. Equals one-third when investors prove that the Accountant acted with negligence and that they either relied on the prospectus or that their loss was caused by the misleading statement or both. Equals zero if restitution from the Accountant is unavailable or the liability standard is intent or gross negligence.

Appoint Equals one if a majority of the members of the Supervisor are unilaterally appointed by the Executive branch of government; equals zero otherwise.

Used for

SECREG;

DISCLOSE;

PRIVATE

SECREG;

DISCLOSE;

PRIVATE

SECREG; DISCLOSE; PRIVATE

SECREG; DISCLOSE; PRIVATE

SECREG;

DISCLOSE; PRIVATE

SECREG;

DISCLOSE; PRIVATE

SECREG; PRIVATE

SECREG; PRIVATE

SECREG; PRIVATE

SECREG; PUBLIC 

Tenure $\quad \begin{aligned} & \text { Equals one if members of the Supervisor cannot be dismissed at the will of the appointing authority; } \\ & \text { equals zero otherwise. }\end{aligned}$

Focus Equals one if separate government agencies or official authorities are in charge of supervising commercial banks and stock exchanges; equals zero otherwise.

Rules

Equals one if the Supervisor can generally issue regulations regarding primary offerings and/or listing rules on stock exchanges without prior approval of other governmental authorities. Equals one-half if the Supervisor can generally issue regulations regarding primary offerings and/or listing rules on stock exchanges only with the prior approval of other governmental authorities. Equals zero otherwise.

Document An index of the power of the Supervisor to command documents when investigating a violation of securities laws. Equals one if the Supervisor can generally issue an administrative order commanding all persons to turn over documents; equals one-half if the Supervisor can generally issue an administrative order commanding publicly traded corporations and/or their directors to turn over documents; equals zero otherwise.

Witness An index of the power of the Supervisor to subpoena the testimony of witnesses when investigating a violation of securities laws. Equals one if the Supervisor can generally subpoena all persons to give testimony; equals one-half if the Supervisor can generally subpoena the directors of publicly-traded corporations to give testimony; equals zero otherwise.

Ord iss An index aggregating stop and do orders that may be directed the Issuer in case of a defective prospectus. The index is formed by averaging the sub-indexes of orders to stop and to do. The subindex of orders to stop equals

one if the Issuer may be ordered to refrain from a broad range of actions; equals one-half if the Issuer may only be ordered to desist from limited actions; equals zero otherwise. The sub-index of orders to do equals one if the Issuer may be ordered to perform a broad range of actions to rectify the violation; equals one-half if the Issuer may only be ordered to perform limited actions; equals zero otherwise. We disregard orders that may be issued by Courts at the request of a private party in a civil lawsuit.

Ord dis An index aggregating stop and do orders that may be directed at the Distributor in case of a defective prospectus. The index is formed by averaging the sub-indexes of orders to stop and to do. The subindex of orders to stop equals one if the Distributor may be ordered to refrain from a broad range of actions; equals one-half if the Distributor may only be ordered to desist from limited actions; equals zero otherwise. The sub-index of orders to do equals one if the Distributor may be ordered to perform a broad range of actions to rectify the violation; equals one-half if the Distributor may only be ordered to perform limited actions; equals zero otherwise. We disregard orders that may be issued by Courts at the request of a private party in a civil lawsuit.

Ord acc An index aggregating stop and do orders that may be directed the Accountant in case of a defective prospectus. The index is formed by averaging the sub-indexes of orders to stop and to do. The subindex of orders to stop equals one if the Accountant may be ordered to refrain from a broad range of actions; equals one-half if the Accountant may only be ordered to desist from limited actions; equals zero otherwise. The sub-index of orders to do equals one if the Accountant may be ordered to perform a broad range of actions to rectify the violation; equals one-half if the Accountant may only be ordered to perform limited actions; equals zero otherwise. We disregard orders that may be issued by Courts at the request of a private party in a civil lawsuit.

Crim dir An index of criminal sanctions applicable to the Issuer's directors and key officers when the prospectus omits material information. We create separate sub-indexes for directors and key officers and average their scores. The sub-index for directors equals zero when directors cannot be held criminally liable when the prospectus is misleading. Equals one-half if directors can be held criminally liable when aware that the prospectus is misleading. Equals one if directors can also be held criminally liable when negligently unaware that the prospectus is misleading. The sub-index for key officers is constructed analogously.

Crim dis An index of criminal sanctions applicable to the Distributor (or its officers) when the prospectus omits material information. Equals zero if the Distributor cannot be held criminally liable when the prospectus is misleading. Equals one-half if the Distributor can be held criminally liable when aware that the prospectus is misleading. Equals one if the Distributor can also be held criminally liable when negligently unaware that the prospectus is misleading.

Crim acc An index of criminal sanctions applicable to the Accountant (or its officers) when the financial statements accompanying the prospectus omit material information. Equals zero if the Accountant cannot be held criminally liable when the financial statements accompanying the prospectus are misleading. Equals one-half if the Accountant can be held criminally liable when aware that the financial statement accompanying the prospectus are misleading. Equals one if the Accountant can also be held criminally liable when negligently unaware that the financial statements accompanying the prospectus are misleading.

\section{SECREG \\ PUBLIC \\ SECREG; \\ PUBLIC}

SECREG; PUBLIC

SECREG; PUBLIC

SECREG; PUBLIC

SECREG; PUBLIC

SECREG; PUBLIC

SECREG; PUBLIC

SECREG; PUBLIC

SECREG; PUBLIC

SECREG; PUBLIC 
Table A2. Sub-indices from "Law and Finance", La Porta et al. (1998)

Sub-index

Mail_prx Equals one if company law or commercial code allows shareholders to mail their vote. Zero otherwise.

LAWFIN; SHARE-

HOLD

Nshsbloc Equals one if the Company Law or Commercial Code allows firms to require that shareholders deposit their shares prior to a General Shareholders Meeting thus preventing them from selling those shares for a number of day and zero otherwise.

Cumu_vot Equals one if the Company Law or Commercial Code allows shareholders to cast their votes for one candidate standing for election to the board of directors, and zero otherwise.

LAWFIN;

SHARE-

HOLD

LAWFIN;

SHARE-

HOLD

Oppr mi Equals one if the Company Law or Commercial Code grants minority shareholders either a judicial venue to challenge the management decisions or the right to step out of the company by requiring the company to purchase their shares when they object to certain fundamental changes, such as merge, assets dispositions and changes in the articles of incorporation. The variable equals zero otherwise.

Esmvotes The minimum percentage shares that entitles a shareholder to call for an Extraordinary Shareholders' meeting. Ranges from. 01 to .33 .

LAWFIN;

SHARE-

HOLD

LAWFIN;

SHARE-

HOLD

Preempt Equals one when company law or commercial code grants shareholders the first opportunity to buy new issues of stock, and this right can be waived only by a shareholders vote. Zero otherwise.

LAWFIN;

SHARE-

HOLD

Ch11 res Equals one if the reorganization procedure imposes restrictions, such as creditors' consent to file for reorganization. It equals $\mathrm{O}$ if there are no such restrictions.

LAWFIN;

CREDITOR

Nauto_st Equals one if the reorganization procedure imposes an automatic stay on the assets of the firm upon filing the organization petition. This restriction prevents secured creditors to gain possession of their security, It equals zero if such restriction does not exist in the law.

Secu_1 $1^{\text {st }} \quad$ Equals one if secured creditors are ranked first in the distribution of the proceeds that result from the disposition of the assets of a bankrupt firm. Equals zero if non-secured creditors, such as the Government and workers, are given absolute priority.

Mgt nst Equals one if the debtor keeps the administration of its property pending the resolution of the reorganization process, and zero otherwise. Equivalently, this variable equals zero when an official appointed by the court or by the creditors, is responsible for the operation of the business during LAWFIN; CREDITOR

LAWFIN; CREDITOR

LAWFIN; reorganization.

CREDITOR 
Table 1a. Summary Statistics - Bilateral variables

Subscript $i$ refers to the source country, and $j$ to the destination country. CPIS is the IMF's Coordinated Portfolio Investment Survey, end of 2001. LLS is La Porta et al. (2003). LLSV is La Porta et al. (1998). Rose is Rose (2002). KKM is Kaufaman et al. (2003). ADEKW is Alesina et al. (2003). WDI is the World Bank World Development Indicators. Hofstede is Hofstede (2001). Author is the author's own coding.

\begin{tabular}{|c|c|c|c|c|c|}
\hline Variable & Description & Source & Obs & Mean & Std. Dev. \\
\hline PORTINV & Total portfolio holdings by $i$ in $j$. & CPIS & 1249 & 7781.757 & 29645.5 \\
\hline EQUITY & Equity holdings by $I$ in $j$. & CPIS & 1139 & 3822.6 & 16551.93 \\
\hline LTD & $\begin{array}{l}\text { Long-term debt holdings by } i \text { in } \\
j \text {. }\end{array}$ & CPIS & 1152 & 4178.188 & 15713.1 \\
\hline STD & Short-term debt holdings $I$ in $j$. & CPIS & 970 & 569.238 & 3860.103 \\
\hline SECREGDIFF & $\begin{array}{l}\text { Differences in total securities } \\
\text { regulation. }\end{array}$ & LLS & 1249 & 7.7865 & 2.4983 \\
\hline DISCLOSEDIFF & $\begin{array}{l}\text { Differences in disclosure } \\
\text { regulation. }\end{array}$ & LLS & 1249 & 1.9047 & 0.971 \\
\hline PRIVATEDIFF & $\begin{array}{l}\text { Differences in the regulation of } \\
\text { private enforcement. }\end{array}$ & LLS & 1249 & 2.925 & 1.281 \\
\hline PUBLICDIFF & $\begin{array}{l}\text { Differences in the regulation of } \\
\text { public enforcement. }\end{array}$ & LLS & 1249 & 4.861 & 1.962 \\
\hline LAWFINDIFF & $\begin{array}{l}\text { Differences in shareholder and } \\
\text { creditor protection. }\end{array}$ & LLSV & 1159 & 4.4379 & 1.6704 \\
\hline SHAREPROTDIFF & $\begin{array}{l}\text { Differences in shareholder } \\
\text { protection. }\end{array}$ & LLSV & 1198 & 2.3098 & 1.1057 \\
\hline CREDITORDIFF & $\begin{array}{l}\text { Differences in creditor } \\
\text { protection. }\end{array}$ & LLSV & 1209 & 1.7212 & 1.0233 \\
\hline TRADE & $\begin{array}{l}\text { Bilateral trade between } i \text { and } j \text { in } \\
\text { US dollars. }\end{array}$ & Rose & 1249 & $2.19 \mathrm{E}+07$ & $6.51 \mathrm{E}+07$ \\
\hline GDPPCDIFF & $\begin{array}{l}\text { Absolute value of differences in } \\
\text { per capita GDP between } i \text { and } j \\
\text { in US dollars. }\end{array}$ & WDI & 1249 & 13234.75 & 9261.758 \\
\hline DIST & Distance between $I$ and $j$. & Rose & 1249 & 4783.427 & 3115.626 \\
\hline BORDER & Dummy for common border. & Rose & 1249 & 0.056 & 0.2301 \\
\hline COMLANG & Dummy for common language. & Rose & 1249 & 0.1985 & 0.399 \\
\hline EU & $\begin{array}{l}\text { Dummy for mutual EU } \\
\text { membership. }\end{array}$ & Author & 1249 & 0.1665 & 0.3727 \\
\hline USI & $\begin{array}{l}\text { Dummy for mutual membership } \\
\text { in the US-Israel FTA. }\end{array}$ & Rose & 1249 & 0.0016 & 0.04 \\
\hline NAFTA & $\begin{array}{l}\text { Dummy for mutual NAFTA } \\
\text { membership. }\end{array}$ & Rose & 1249 & 0.0016 & 0.04 \\
\hline ANZERTA & $\begin{array}{l}\text { Dummy for mutual membership } \\
\text { in ANZERTA. }\end{array}$ & Rose & 1249 & 0.0016 & 0.04 \\
\hline MERCOSUR & $\begin{array}{l}\text { Dummy for mutual membership } \\
\text { in MERCOSUR. }\end{array}$ & Rose & 1249 & 0.0096 & 0.0975 \\
\hline ASEAN & $\begin{array}{l}\text { Dummy for mutual membership } \\
\text { in ASEAN. }\end{array}$ & Rose & 1249 & 0.014 & 0.119 \\
\hline LEGDIFF & Dummy for different legal origin. & LLSV & 1249 & 0.7181 & 0.45 \\
\hline COLONY & $\begin{array}{l}\text { Dummy for sharing a colonial } \\
\text { past. }\end{array}$ & Rose & 1249 & 0.036 & 0.188 \\
\hline RULELAWDIFF & $\begin{array}{l}\text { Absolute value of differences in } \\
\text { the Rule of law. }\end{array}$ & LLSV & 1249 & 2.584 & 2.004 \\
\hline GOVEFFDIFF & $\begin{array}{l}\text { Absolute value of differences in } \\
\text { the Government effectiveness. }\end{array}$ & KKM & 1249 & 0.9496 & 0.6972 \\
\hline RELIGIONDIFF & $\begin{array}{l}\text { Index of differences in religious } \\
\text { beliefs. }\end{array}$ & ADEKW & 1179 & 0.7753 & 0.534 \\
\hline CULTUREDIFF & $\begin{array}{l}\text { Index of differences in cultural } \\
\text { values. }\end{array}$ & Hofstede & 1205 & 1.043 & 0.432 \\
\hline
\end{tabular}


Table 1b. Summary statistics - Country-level variables

LLS is La Porta et al. (2003). KKM is Kaufmann et al. (2003). BLL is Beck et al. (2000). WDI is the World Bank World Development Indicators. Author is the author's own coding.

\begin{tabular}{|c|c|c|c|c|c|}
\hline Variable & Description & Source & Obs & Mean & Std. Dev. \\
\hline SECREG & Index of securities regulation. & LLS & 38 & 9.961 & 3.978 \\
\hline DISCLOSE & Index of disclosure regulation. & LLS & 38 & 2.731 & 1.245 \\
\hline PRIVATE & $\begin{array}{l}\text { Index of private enforcement } \\
\text { regulation. }\end{array}$ & LLS & 38 & 4.198 & 1.872 \\
\hline PUBLIC & $\begin{array}{l}\text { Index of public enforcement } \\
\text { regulation. }\end{array}$ & LLS & 38 & 5.768 & 2.698 \\
\hline GDPPC & GDP per capita in US dollars. & WDI & 38 & 16294 & 11167 \\
\hline GDP & GDP in millions of US dollars. & WDI & 38 & 737397 & 1725445 \\
\hline EFF_JUD & Index of judicial efficiency. & LLS & 38 & 7.942 & 2.186 \\
\hline GOVEFF & $\begin{array}{l}\text { Index of government } \\
\text { effectiveness. }\end{array}$ & KKM & 38 & 1.141 & 0.858 \\
\hline TRADING & $\begin{array}{l}\text { Stock market trading to GDP- } \\
\text { ratio. }\end{array}$ & BLL & 38 & 0.276 & 0.277 \\
\hline EU & Dummy for EU membership. & Author & 38 & 0.384 & 0.493 \\
\hline MKTCAP & $\begin{array}{l}\text { External market capitalization to } \\
\text { GDP ratio. }\end{array}$ & LLS & 38 & 0.46 & 0.388 \\
\hline POP & Population size in millions. & WDI & 38 & 47.212 & 60.178 \\
\hline AREA & Land area in square kilometers. & WDI & 38 & 1297201 & 2572906 \\
\hline
\end{tabular}


Table 2. Differences in securities regulation

This table shows the country-pairs with differences in securities regulation in the lowest and highest percentiles, as well as at the median.

\begin{tabular}{llr}
\hline Country 1 & Country 2 & SECREGDIFF \\
\hline Hong Kong & Malaysia & 0.5 \\
Austria & Germany & 0.83 \\
United States & Philippines & 2 \\
Hong Kong & Singapore & 2.5 \\
Greece & Spain & 2.66 \\
Finland & Greece & 2.66 \\
& & \\
Austria & Uruguay & 7.75 \\
New Zealand & Thailand & 7.75 \\
France & Thailand & 7.75 \\
Indonesia & Singapore & 7.75 \\
Switzerland & Thailand & 7.75 \\
Italy & Thailand & 7.75 \\
& & \\
United States & Germany & 14 \\
United States & Austria & 14.17 \\
Germany & Singapore & 14.48 \\
Austria & Singapore & 14.65 \\
United States & Belgium & 14.68 \\
\hline
\end{tabular}




\section{Table 3. Main results}

The dependent variable is the log of $1+$ portfolio holdings by country $i$ in country $j$. Source and destination country fixed effects are included. Standard errors, clustered on country-pair, appear beneath the point estimates. Significance at $1(* * *), 5(* *)$, and 10 percent $(*)$ levels indicated. Instruments in the 2SLS-estimates are a dummy of differences in legal origin and a dummy of common colonial history. F-test is the F-statistics of the instruments from the first-stage regression. OID reports the p-value from a Hansen test of over-identifying restrictions.

\begin{tabular}{|c|c|c|c|c|c|c|c|c|}
\hline & (1) & (2) & (3) & (4) & $(5)$ & (6) & (7) & (8) \\
\hline Est. method & OLS & 2SLS & OLS & 2SLS & OLS & 2SLS & OLS & 2SLS \\
\hline \multirow[t]{2}{*}{ SECREGDIFF } & -0.0537 & -0.2533 & & & & & & \\
\hline & $0.0196 * * *$ & $0.0856 * * *$ & & & & & & \\
\hline \multirow[t]{2}{*}{ DISCLOSEDIFF } & & & -0.1576 & -0.8672 & & & & \\
\hline & & & $0.0535^{* * *}$ & $0.3118 * * *$ & & & & \\
\hline \multirow[t]{2}{*}{ PRIVATEDIFF } & & & & & -0.0861 & -0.8946 & & \\
\hline & & & & & $0.0404 * *$ & $0.3504 * * *$ & & \\
\hline \multirow[t]{2}{*}{ PUBLICDIFF } & & & & & & & -0.0509 & -0.3534 \\
\hline & & & & & & & $0.0239 * *$ & $0.1248 * * *$ \\
\hline \multirow[t]{2}{*}{$\operatorname{Ln}(\mathrm{DIST})$} & -0.2962 & -0.2545 & -0.318 & -0.3661 & -0.316 & -0.3971 & -0.2916 & -0.1982 \\
\hline & $0.128 * *$ & $0.1314 * *$ & $0.1274 * * *$ & $0.1279 * * *$ & $0.1288 * * *$ & $0.1449 * * *$ & $0.1289 * *$ & 0.1435 \\
\hline \multirow[t]{2}{*}{ Ln(GDPPCDIFF) } & -0.3635 & -0.3676 & -0.3761 & -0.4379 & -0.3698 & -0.4397 & -0.359 & -0.3391 \\
\hline & $0.0807 * * *$ & $0.0797 * * *$ & $0.08063 * * *$ & $0.0886 * * *$ & $0.0809 * * *$ & $0.0968 * * *$ & $0.0813 * * *$ & $0.0832 * * *$ \\
\hline \multirow[t]{2}{*}{ Ln(TRADE) } & 0.4797 & 0.3653 & 0.4619 & 0.2438 & 0.4733 & 0.125 & 0.5032 & 0.4603 \\
\hline & $0.081 * * *$ & $0.0978 * * *$ & $0.0811 * * *$ & $0.1322 *$ & $0.0813 * * *$ & 0.1812 & $0.0806 * * *$ & $0.0901 * * *$ \\
\hline \multirow{2}{*}{ COMLANG } & 0.5204 & 0.2366 & 0.509 & 0.1143 & 0.5261 & -0.1376 & 0.566 & 0.3844 \\
\hline & $0.148 * * *$ & 0.1972 & $0.1463 * * *$ & 0.2368 & $0.1507 * * *$ & 0.3345 & $0.1457 * * *$ & $0.18 * *$ \\
\hline \multirow[t]{2}{*}{ BORDER } & -0.4774 & -0.3131 & -0.4774 & -0.2784 & -0.4993 & -0.2906 & -0.4928 & -0.3219 \\
\hline & $0.21 * *$ & 0.2376 & $0.2041 * *$ & 0.2369 & $0.2066 * *$ & 0.2639 & $0.2124 * *$ & 0.2581 \\
\hline \multirow[t]{2}{*}{ EU } & 0.5943 & 0.5797 & 0.5214 & 0.1753 & 0.5792 & 0.3996 & 0.6058 & 0.6508 \\
\hline & $0.174 * * *$ & $0.1902 * * *$ & $0.1775 * * *$ & 0.2487 & $0.1753 * * *$ & 0.2404 & $0.1743 * * *$ & $0.2027 * * *$ \\
\hline \multirow[t]{2}{*}{ USI } & 0.8086 & 0.1008 & 1.0681 & 1.3794 & 1.0149 & 1.1652 & 0.8088 & -0.3195 \\
\hline & $0.272 * * *$ & 0.4461 & $0.2702 * * *$ & $0.3768 * * *$ & $0.2668 * * *$ & $0.4208 * * *$ & $0.2758 * * *$ & 0.5739 \\
\hline \multirow[t]{2}{*}{ NAFTA } & -1.3419 & -2.6812 & -1.2184 & -2.284 & -1.2756 & -4.0362 & -1.1496 & -2.1466 \\
\hline & $0.302 * * *$ & $0.6775^{* * *}$ & $0.2734 * * *$ & $0.5949 * * *$ & $0.2959 * * *$ & $1.2877 * * *$ & $0.2754 * * *$ & $0.5414 * * *$ \\
\hline \multirow[t]{2}{*}{ ANZERTA } & 1.2978 & 2.2657 & 1.3307 & 2.6505 & 1.2432 & 3.1745 & 1.1628 & 1.9068 \\
\hline & $0.336^{* * *}$ & $0.5507 * * *$ & $0.3445 * * *$ & $0.6824 * * *$ & $0.3444 * * *$ & $0.9114 * * *$ & $0.3345 * * *$ & $0.5055^{* * *}$ \\
\hline \multirow[t]{2}{*}{ MERCOSUR } & 1.5019 & 1.7862 & 1.4473 & 1.5455 & 1.4244 & 1.4143 & 1.4987 & 1.9331 \\
\hline & $0.576^{* * *}$ & $0.6088 * * *$ & $0.5405 * * *$ & $0.5373 * * *$ & $0.5618 * * *$ & $0.6409 * *$ & $0.5864 * * *$ & $0.6686^{* * *}$ \\
\hline \multirow[t]{2}{*}{ ASEAN } & 0.7055 & 0.4819 & 0.678 & 0.2838 & 0.7352 & 0.4489 & 0.7266 & 0.495 \\
\hline & 0.467 & 0.4678 & 0.474 & 0.5256 & 0.4696 & 0.5022 & 0.4695 & 0.4879 \\
\hline Fixed effects & YES & YES & YES & YES & YES & YES & YES & YES \\
\hline $\mathrm{R} 2$ & 0.87 & 0.86 & 0.87 & 0.85 & 0.87 & 0.82 & 0.87 & 0.85 \\
\hline \# OBS & 1249 & 1249 & 1249 & 1249 & 1249 & 1249 & 1249 & 1249 \\
\hline F-test & & 38.5 & & 22.7 & & 13.4 & & 28.6 \\
\hline OID (p-value) & & 0.34 & & 0.14 & & 0.39 & & 0.34 \\
\hline
\end{tabular}


Table 4. Another look at the size of the effects (dropping FE)

2SLS-estimates. The dependent variable is the $\log$ of $1+$ portfolio holdings by country $i$ in country $j$. In column (1), the total index of securities regulation is used, in (2) the disclosure index, in (3) the private enforcement index, and in (4) the public enforcement index. Regulatory difference is the coefficient of the respective index of regulatory difference, destination regulation index is the coefficient of the capital importing country's index of securities regulation, source regulation index is the coefficient of the capital exporting country's index of securities regulation. In Panel A, the indices themselves are used, in Panel B $\log (1+$ index $)$ are used. All regressions include the bilateral controls that appear in Table 3. In addition, the product of both countries' GDP and land area are included. Further, source and destination country per capita GDP, external market capitalization, an index of judicial efficiency, an index of government effectiveness, the value traded in the stock market to GDP ratio, a dummy variable for EU membership, and the log of population size. Standard errors, clustered on country-pair, appear beneath the point estimates. Significance at $1(* * *), 5(* *)$, and 10 percent $(*)$ levels indicated. Instruments in the 2SLS-estimates are a dummy of differences in legal origin, a dummy of common colonial history, and dummies of legal origin for exporter and importer, respectively. F-test is the Fstatistics of the instruments from the first-stage regression for the difference index, the destination country's index, and the source country's index. OID reports the p-value from a Hansen test of over-identifying restrictions.

\begin{tabular}{|c|c|c|c|c|}
\hline Panel A: log-level & $(1 \mathrm{~A})$ & $(2 \mathrm{~A})$ & $(3 \mathrm{~A})$ & $(4 \mathrm{~A})$ \\
\hline Est. method: & 2SLS & 2SLS & 2SLS & 2SLS \\
\hline Index of regulation: & SECREG & DISCLOSE & PRIVATE & PUBLIC \\
\hline Regulatory difference & -0.3232 & -0.6741 & -0.6446 & -0.472 \\
\hline index & $0.1002 * * *$ & $0.3078 * *$ & $0.2534 * * *$ & $0.1446^{* * *}$ \\
\hline Destination regulation & 0.0837 & 0.1104 & 0.1171 & 0.1291 \\
\hline index & $0.027 * * *$ & 0.087 & $0.0673 *$ & $0.0413 * * *$ \\
\hline Source regulation & 0.0478 & -0.0753 & -0.0229 & 0.0895 \\
\hline index & $0.0283 *$ & 0.0852 & 0.0669 & $0.0423 * *$ \\
\hline $\mathrm{R} 2$ & 0.77 & 0.78 & 0.77 & 0.75 \\
\hline \# OBS & 1249 & 1249 & 1249 & 1249 \\
\hline F-test (diff. index) & 14.4 & 6.6 & 6.2 & 10.2 \\
\hline F-test (destination index) & 173.3 & 107.6 & 78.1 & 121.6 \\
\hline F-test (source index) & 182.2 & 123.39 & 84.4 & 124.1 \\
\hline OID (p-value) & 0.29 & 0.3 & 0.42 & 0.21 \\
\hline Panel B: log-log & $(1 \mathrm{~B})$ & $(2 \mathrm{~B})$ & $(3 \mathrm{~B})$ & $(4 B)$ \\
\hline Est. method: & 2SLS & 2SLS & 2SLS & 2SLS \\
\hline Index of regulation: & SECREG & DISCLOSE & PRIVATE & PUBLIC \\
\hline Log of Regulatory & -2.425 & -1.828 & -2.0653 & -2.6884 \\
\hline difference index & $0.818 * * *$ & $0.868 * *$ & $0.8769 * * *$ & $0.8594 * * *$ \\
\hline Log of Destination & 0.8548 & 0.4107 & 0.5727 & 0.7769 \\
\hline regulation index & $0.2844 * * *$ & 0.3167 & $0.3069 * *$ & $0.2578 * * *$ \\
\hline Log of Source & 0.4698 & -0.323 & -0.1621 & 0.5476 \\
\hline regulation index & 0.2897 & 0.3102 & 0.2987 & $0.2635^{* *}$ \\
\hline $\mathrm{R} 2$ & 0.77 & 0.78 & 0.78 & 0.73 \\
\hline \# OBS & 1249 & 1249 & 1249 & 1249 \\
\hline F-test (diff. index) & 16.4 & 6.6 & 7.8 & 10.9 \\
\hline F-test (destination index) & 222.3 & 61.9 & 58.2 & 115.1 \\
\hline F-test (source index) & 232.3 & 69.9 & 62.1 & 116.3 \\
\hline OID (p-value) & 0.26 & 0.34 & 0.33 & 0.23 \\
\hline
\end{tabular}


Table 5. Rich vs. poor countries

2SLS-estimates. The dependent variable is the $\log$ of $1+$ portfolio holdings by country $i$ in country $j$. In column (1), only rich countries (above median per capita GDP) are included, in (2), only poor countries (below median per capita GDP) are included. In (3), rich destination (country $j$ ) and all sources (country $i$ ) are included. In (4), poor $j$-countries and all $i$-countries are included. In (5), all $j$-countries and rich $i$-countries are included. In (6), all $j$-countries and poor $i$-countries are included. All regressions include the bilateral controls that appear in Table 3 . Source and destination country fixed effects are included. Standard errors, clustered on country-pair, appear beneath the point estimates. Significance at $1(* * *), 5(* *)$, and 10 percent $(*)$ levels indicated. Instruments are a dummy of differences in legal origin and a dummy of common colonial history. F-test is the F-statistics of the instruments from the first-stage regression. OID reports the p-value from a Hansen test of over-identifying restrictions.

\begin{tabular}{|c|c|c|c|c|c|c|}
\hline & (1) & (2) & (3) & (4) & (5) & (6) \\
\hline Est. method: & 2SLS & 2SLS & 2SLS & 2SLS & 2SLS & 2SLS \\
\hline \multirow[t]{2}{*}{ Sample: } & $\mathrm{R}$ (dest) & $\mathrm{P}$ (dest) & $\mathrm{R}$ (dest) & $\mathrm{P}$ (dest) & All (dest) & All (dest) \\
\hline & R (source) & $\mathrm{P}$ (source) & All (source) & All (source) & R (source) & $\mathrm{P}$ (source) \\
\hline \multirow[t]{2}{*}{ SECREGDIFF } & -0.2118 & -0.0777 & -0.2578 & -0.2063 & -0.1618 & -0.2269 \\
\hline & $0.1008 * *$ & 0.1859 & $0.0957 * * *$ & $0.1279 *$ & $0.079 * *$ & $0.1242 *$ \\
\hline Fixed effects & YES & YES & YES & YES & YES & YES \\
\hline $\mathrm{R} 2$ & 0.81 & 0.74 & 0.88 & 0.84 & 0.87 & 0.78 \\
\hline \# OBS & 303 & 261 & 633 & 616 & 658 & 591 \\
\hline F-test & 12.4 & 10.3 & 19.3 & 18.9 & 19.6 & 19.8 \\
\hline OID (p-value) & 0.2 & 0.08 & 0.52 & 0.13 & 0.36 & 0.01 \\
\hline
\end{tabular}


Table 6. Equity and long-term debt holdings

2SLS-estimates. The dependent variables are the log of 1+equity holdings or 1+long-term debt holdings by country $i$ in country $j$. In columns (1) and (2), the total index of securities regulation is used, in (3) and (4) the disclosure index, in (5) and (6) the private enforcement index, and in (7) and (8) the public enforcement index. Regulatory difference index is the coefficient of the respective index of regulatory difference. All regressions include the bilateral controls that appear in Table 3. Source and destination country fixed effects are included. Standard errors, clustered on country-pair, appear beneath the point estimates. Significance at $1(* * *), 5(* *)$, and 10 percent $(*)$ levels indicated. Instruments are a dummy of differences in legal origin and a dummy of common colonial history. F-test is the F-statistics of the instruments from the first-stage regression. OID reports the p-value from a Hansen test of over-identifying restrictions.

\begin{tabular}{|c|c|c|c|c|c|c|c|c|}
\hline & (1) & (2) & (3) & (4) & (5) & (6) & (7) & (8) \\
\hline Est. method & 2SLS & 2SLS & 2SLS & 2SLS & 2SLS & 2SLS & 2SLS & 2SLS \\
\hline $\begin{array}{l}\text { Dependent } \\
\text { variable }\end{array}$ & Equity & LT debt & Equity & LT debt & Equity & LT debt & Equity & LT debt \\
\hline SECREGDIFF & $\begin{array}{l}-0.2381 \\
0.0784 * * *\end{array}$ & $\begin{array}{l}-0.133 \\
0.0756^{*}\end{array}$ & & & & & & \\
\hline DISCLOSEDIFF & & & $\begin{array}{l}-0.8556 \\
0.3062 * * *\end{array}$ & $\begin{array}{l}-0.4544 \\
0.2885\end{array}$ & & & & \\
\hline PRIVATEDIFF & & & & & $\begin{array}{l}-0.8334 \\
0.3289 * * *\end{array}$ & $\begin{array}{l}-0.5655 \\
0.3073 *\end{array}$ & & \\
\hline PUBLICDIFF & & & & & & & $\begin{array}{l}-0.3332 \\
0.1137 * * *\end{array}$ & $\begin{array}{l}-0.1715 \\
0.1041 *\end{array}$ \\
\hline Fixed effects & YES & YES & YES & YES & YES & YES & YES & YES \\
\hline $\mathrm{R} 2$ & 0.87 & 0.86 & 0.86 & 0.87 & 0.84 & 0.85 & 0.86 & 0.86 \\
\hline \# OBS & 1135 & 1152 & 1135 & 1152 & 1135 & 1152 & 1135 & 1152 \\
\hline F-test & 36.5 & 36.3 & 20.3 & 18.9 & 12.9 & 10.9 & 26.9 & 28.7 \\
\hline OID (p-value) & 0.74 & 0.01 & 0.48 & 0.01 & 0.82 & 0.05 & 0.69 & 0.01 \\
\hline
\end{tabular}




\section{Table 7. Differences in investor protection}

2SLS-estimates. The dependent variables are the log of 1 +portfolio holdings, $1+$ equity holdings or 1+long-term debt holdings by country $i$ in country $j$. In columns (1), (2) and (3), LAWFINDIFF from La Porta et al. (1998) is used as the index of regulatory differences, in (4), (5) and (6), the difference in shareholder protection is used as the index of regulatory differences, in (7), (8) and (9), the difference in creditor protection is used as the index of regulatory differences. Regulatory difference index is the coefficient of the respective index of regulatory difference. All regressions include the bilateral controls that appear in Table 3 . Source and destination country fixed effects are included. Standard errors, clustered on country-pair, appear beneath the point estimates. Significance at $1(* * *), 5(* *)$, and 10 percent $(*)$ levels indicated. Instruments are a dummy of differences in legal origin and a dummy of common colonial history. F-test is the F-statistics of the instruments from the first-stage regression. OID reports the pvalue from a Hansen test of over-identifying restrictions.

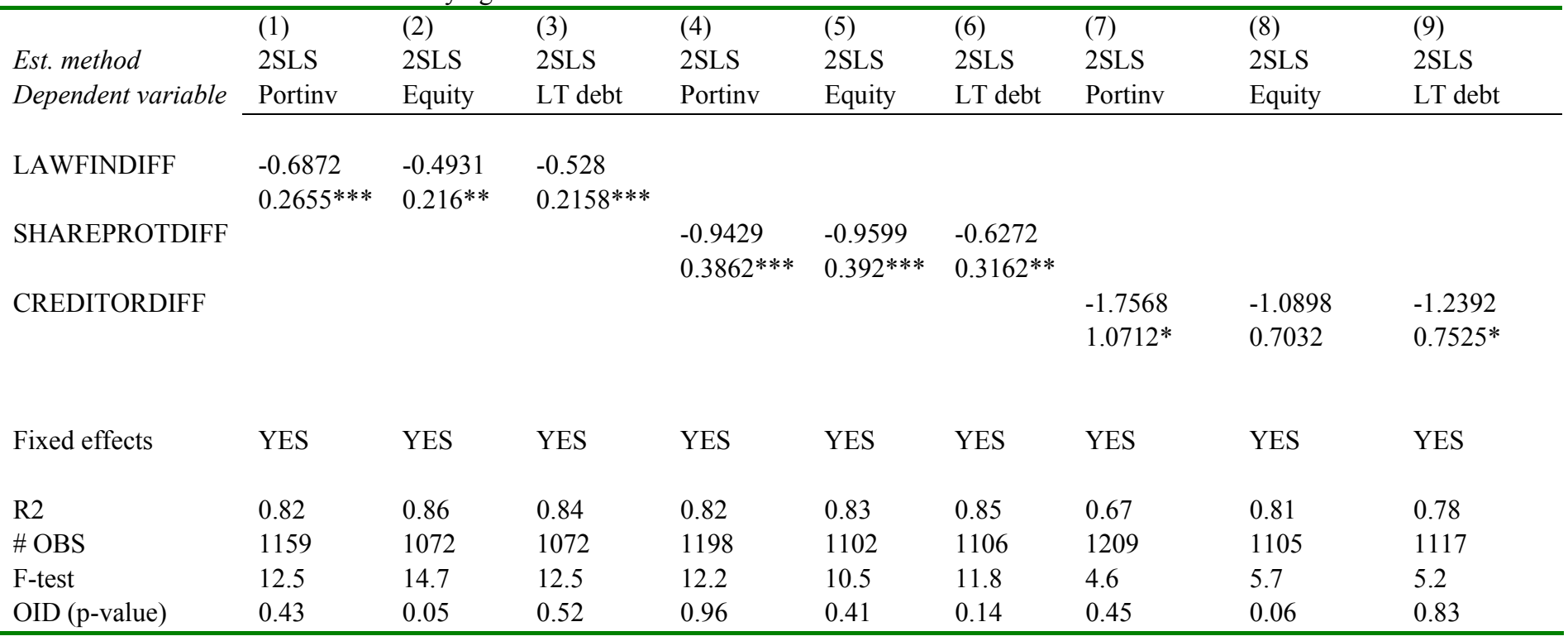


Table 8. Country exclusions and differences in institutions and culture

2SLS estimates. The dependent variable is the log of $1+$ portfolio holdings by country $i$ in country $j$. In column (1), the US and UK are excluded from the sample. In (2), Singapore and Hong Kong are excluded. In column (3), the absolute difference in the Rule of law index, in (4), the absolute difference in the Government Effectiveness index, in (5), the index of differences in religious beliefs, in (6), the index of differences in cultural values, and in (7), all these four indices are added to the regression. All regressions include the bilateral controls that appear in Table 3. Source and destination country fixed effects are included. Standard errors clustered at country-pair appear beneath the point estimates. Significance at $1(* * *), 5(* *)$, and 10 percent $(*)$ levels indicated. Instruments are a dummy of differences in legal origin and a dummy of common colonial history. Ftest is the F-statistics of the instruments from the first-stage regression. OID reports the p-value from a Hansen test of over-identifying restrictions.

\begin{tabular}{|c|c|c|c|c|c|c|c|}
\hline & (1) & $(2)$ & (3) & (4) & $(5)$ & $(6)$ & (7) \\
\hline Est. method & 2SLS & 2SLS & 2SLS & 2SLS & 2SLS & 2SLS & 2SLS \\
\hline Sample & $\begin{array}{l}\text { US-UK } \\
\text { excl. }\end{array}$ & $\begin{array}{l}\text { SP-HK } \\
\text { excl. }\end{array}$ & Full & Full & Full & Full & Full \\
\hline \multirow[t]{2}{*}{ SECREGDIFF } & -0.2886 & -0.2263 & -0.264 & -0.252 & -0.1802 & -0.255 & -0.2395 \\
\hline & $0.1128 * * *$ & $0.1064 * *$ & $0.0847 * * *$ & $0.0848 * * *$ & $0.071 * * *$ & $0.098 * * *$ & $0.0901 * * *$ \\
\hline \multirow[t]{2}{*}{ RULELAWDIFF } & & & -0.1897 & & & & -0.2325 \\
\hline & & & $0.0448 * * *$ & & & & $0.0521 * * *$ \\
\hline \multirow[t]{2}{*}{ GOVEFFDIFF } & & & & -0.0398 & & & 0.1648 \\
\hline & & & & 0.1124 & & & 0.1277 \\
\hline \multirow[t]{2}{*}{ RELIGIONDIFF } & & & & & -0.4823 & & -0.4124 \\
\hline & & & & & $0.1189 * * *$ & & $0.1233 * * *$ \\
\hline \multirow[t]{2}{*}{ CULTUREDIFF } & & & & & & -0.2189 & -0.0248 \\
\hline & & & & & & 0.1347 & 0.1471 \\
\hline Fixed effects & YES & YES & YES & YES & YES & YES & YES \\
\hline $\mathrm{R} 2$ & 0.83 & 0.88 & 0.86 & 0.86 & 0.87 & 0.86 & 0.87 \\
\hline \# OBS & 1100 & 1120 & 1249 & 1249 & 1179 & 1205 & 1136 \\
\hline F-test & 26.8 & 24.5 & 38.5 & 39.1 & 38.7 & 29.2 & 27.4 \\
\hline OID-test & 0.12 & 0.47 & 0.33 & 0.3 & 0.21 & 0.36 & 0.32 \\
\hline
\end{tabular}


Table 9. The sign of the reverse causality

The dependent variable is SECREGDIFF, the differences in securities regulation between countries $i$ and $j$. Source and destination country fixed effects are included. Standard errors, clustered on country-pair, appear beneath the point estimates. Significance at $1(* * *), 5(* *)$, and 10 percent $(*)$ levels indicated. Instruments in the 2SLS-estimates are $\ln \left(\mathrm{POP}_{i}\right) \times \ln \left(\mathrm{POP}_{j}\right), \ln \left(\mathrm{GDP}_{i}\right) \times \ln \left(\mathrm{GDP}_{j}\right)$, and the absolute value of differences in the rule of law index. F-test is the F-statistics of the instruments from the first-stage regression. OID reports the p-value from a Hansen test of over-identifying restrictions.

\begin{tabular}{|c|c|c|}
\hline \multirow[b]{2}{*}{ Est. Method } & (1) & (2) \\
\hline & OLS & 2SLS \\
\hline \multirow[t]{2}{*}{$\ln (1+$ PORTINV $)$} & -0.1122 & 0.9439 \\
\hline & $0.0547 * *$ & $0.4819 * *$ \\
\hline \multirow[t]{2}{*}{ LEGDIFF } & 1.1901 & 1.4584 \\
\hline & $0.26^{* * *}$ & $0.2814 * * *$ \\
\hline \multirow[t]{2}{*}{ COLONY } & -1.3956 & -2.0048 \\
\hline & $0.746^{* *}$ & $0.8532 * * *$ \\
\hline \multirow[t]{2}{*}{$\ln (\mathrm{DIST})$} & 0.4189 & 0.8233 \\
\hline & $0.2365^{*}$ & $0.3077 * * *$ \\
\hline \multirow[t]{2}{*}{ BORDER } & 1.1143 & 1.7828 \\
\hline & $0.5041 * *$ & $0.5978 * * *$ \\
\hline \multirow[t]{2}{*}{ COMLANG } & -0.5759 & -0.9806 \\
\hline & 0.369 & $0.4419 * *$ \\
\hline \multirow[t]{2}{*}{$\ln (\mathrm{GDPPCDIFF})$} & -0.15289 & 0.206 \\
\hline & 0.137024 & 0.2218 \\
\hline \multirow[t]{2}{*}{$\ln (\mathrm{TRADE})$} & -0.2582 & -0.725 \\
\hline & $0.1571^{*}$ & $0.2932 * * *$ \\
\hline \multirow[t]{2}{*}{$\mathrm{EU}$} & -0.1883 & -0.8679 \\
\hline & 0.4185 & 0.5558 \\
\hline \multirow[t]{2}{*}{ USI } & -3.2643 & -4.3403 \\
\hline & $0.7479 * * *$ & $0.906 * * *$ \\
\hline \multirow[t]{2}{*}{ NAFTA } & -7.0142 & -6.0984 \\
\hline & $0.9192 * * *$ & $1.003 * * *$ \\
\hline \multirow[t]{2}{*}{ ANZERTA } & 4.9003 & 3.7554 \\
\hline & $0.768 * * *$ & $0.9818 * * *$ \\
\hline \multirow[t]{2}{*}{ MERCOSUR } & 1.4441 & -0.0896 \\
\hline & $0.8967 *$ & 1.1704 \\
\hline \multirow[t]{2}{*}{ ASEAN } & -1.3724 & -2.2642 \\
\hline & $0.7985^{*}$ & $0.983 * *$ \\
\hline Fixed effects & YES & YES \\
\hline R2 & 0.36 & 0.29 \\
\hline \# OBS & 1249 & 1249 \\
\hline F-test & & 9.78 \\
\hline OID & & 0.31 \\
\hline
\end{tabular}

